\title{
Oral Complaints of Complete Denture Wearing Elderly Patients And Their Relation With Age \& Gender
}

\author{
Kamran Parvez ${ }^{1}$ \\ Khurram Parvez ${ }^{2}$ \\ Rooha Sultan ${ }^{3}$ \\ Azam Muhammad Aliuddin ${ }^{4}$ \\ BDS, MDS \\ BDS, MDS \\ BDS \\ BDS
}

OBJECTIVE: The aims of this study were to observe and determine the oral complaints of patients aged 50 years or older and their satisfaction with their complete dentures by means of a simple questionnaire.

METHODOLOGY: A cross-sectional questionnaire based descriptive study was conducted at the Department of Prosthodontics Dr.Ishratul Ebad Khan Institute of Oral Health Sciences, Dow University of Health Sciences, and at the Department of Prosthodontics, Fatima Jinnah Dental College, Karachi Pakistan during the period of May 2014 to August 2014. Data relating to 51 patients wearing complete dentures was collected using structured eight categorized questionnaire, three point scale Performa. Patient history was taken and examination done. Demographic view obtained consists of age, gender; fitting place and the duration that complete denture has been in use for. The recorded data was entered into SPSS version 17. RESULTS: There were total 51 patients with gender distribution of $72.5 \%$ (37) males and $27.4 \%$ (14) females. The responses for the questionnaire item 7 with subpart showed, in all cases that the majority of elder people reported a range of problems with their dentures. Pain was reported as the most common complaint of these complete denture wearers. There was no significant relationship between the patient's gender and type or number of complaints. Conclusion: Study results showed low quality of life of complete denture wearers as they frequently had problems in eating, social interaction and communication. KEYWORDS: Geriatric Dentistry, Oral Health of Elderly People, Oral Complaints in Elderly People, Complete denture evaluation, Patient satisfaction.

HOW TO CITE: Parvez K, Pervez K, Sultan R, Aliuddin AM. Oral complaints of complete denture wearing elderly patients and their relation with age \& gender. J Pak Dent Assoc 2020;29(3):140-143.

DOI: https://doi.org/10.25301/JPDA.293.140

Received: 29 August 2019, Accepted: 09 May 2020

\section{INTRODUCTION}

$\mathrm{W}$ ith the advances in medicine and increasing awareness a high proportion of elderly population (aged about 65 years and above) are more evident in developed countries. ${ }^{1}$ The need to find effective and applicable solutions to the problems of elderly people has therefore become a priority for the improvement of their quality of life1. Physical, psychological and intellectual problems can be highlighted among various others that the elderly population comes across. Aging in a way is associated with a number of limitations. Some of these might be

1. Lecturer, Department of Prosthodontics, Dr Ishrat ul Ebad Khan Institute of Oral Health Sciences Dow University of Health Sciences.

2. Associate Professor, Department of Science of Dental Materials, Dr Ishrat ul Ebad Khan Institute of Oral Health Sciences.

3. Lecturer, Department of Science of Dental Materials, Dr Ishrat ul Ebad Khan Institute of Oral Health Sciences.

4. Former Chief Resident (FCPS), Department of Operative Dentistry, Fatima Jinnah Dental College.

Corresponding author: "Dr. Rooha Sultan" < rooha.sultan@ duhs.edu.pk > recognizable in deteriorating intelligence, sight, hearing, muscle strength and bone mineral contents and also in evaluation of their own health. ${ }^{2-3}$

Oral health may involve many physical and psychological issues. Wearing dentures affects eating, speaking, facial expressions, and appearance of a person. A complaint is defined as an utterance of pain, discomfort, or dissatisfaction. ${ }^{4}$ The post-op care of patients is an essential part of a complete denture service. Generally, patients expect immense amount of positive difference between their new and previous dentures in terms of esthetics and function alike. Unavoidable compromises are not easily accepted. ${ }^{5}$ Hindrances in retention and stability, esthetics, chewing and accumulation of food are the most commonly reported complains of complete denture wearers. ${ }^{6-10} \mathrm{~A}$ recent study reports that oral health of edentulous individuals is associated with the avoidance of food and their satisfaction with dentures. The completely edentate patients reported better oral health and ease with their dentures than the partially edentate. ${ }^{11}$ 
An unsatisfactory denture can be the cause of insomnia and other irritating changes in eating and social behaviors of an individual. These changes can lead to deterioration of self-confidence making older people become less active socially. The psychological effects of such problems are important and should be considered in people of all ages. ${ }^{12-14}$ In this study we tried to observe the major oral complaints of elderly denture wearing patients and also if there is any age and gender association involved.

\section{METHODOLOGY}

A cross-sectional questionnaire based descriptive study with a convenience sampling technique was adopted for this research. During the period from May 2014 to August 2014 , data of 51 patients of both genders having problems with their complete dentures were collected, after taking consent, using a structured eight categories questionnaire, three point scale Performa presented in Figure $1 .{ }^{16}$ The participants of study were patients who reported in Prosthodontics department of Dr Ishrat ul Ebad Khan Institute of Oral Health Sciences, Dow University of Health Sciences, and in the Department of Prosthodontics, Fatima Jinnah Dental College, Karachi. Inclusion criteria of patients were the ones who had been using dentures for at least 6 months with satisfactory general medical condition and psychological health. All those elderly complete denture wearers suffering from any systemic disorder, chronic debilitating conditions were excluded from study. Age range of patients was between 50 to 75 years. After taking history and demographic data from each patient, intra oral clinical examination and prosthesis examination was carried out by the principal investigator and a co-investigator. During history taking, patients were asked about the duration of denture use, fabrication of dentures and about retention, pain, mastication, aesthetics and oral hygiene associated with the prosthesis. During clinical examination retention, stability, occlusion, oral hygiene and prosthesis hygiene were assessed. The collected data was computed using SPSS Version 17. Ethical Approval was obtained (BEH No. JAN-2014-OPR01)

\section{RESULTS}

Of the total 51 patients, $72.5 \%$ (37) were male and $27.4 \%$ (14) female. Patients were divided into five groups according to their ages. Group I (50 to 55 yrs.), Group II (56 to 60 yrs.), Group III (61 to 65 yrs.), Group IV (66 to 70yrs), Group V (70 yrs. \& above) as shown in Table 1. The duration of use of dentures is given in Table 2. The responses for the questionnaire item number 7 with subparts are documented in Table 3. Problems associated with dentures
Table 1: Age distribution of patients

\begin{tabular}{|c|c|c|}
\hline \multirow{2}{*}{ Group I } & Age Group (Years) & Numbers (\%) \\
\cline { 2 - 3 } & $50-55$ & $8(15.6 \%)$ \\
\hline Group II & $56-60$ & $6(11.7 \%)$ \\
\hline Group III & $61-65$ & $20(39.2 \%)$ \\
\hline Group IV & $66-70$ & $14(27.4 \%)$ \\
\hline Group V & $70 \&$ above & $3(5.8 \%)$ \\
\hline Total & & 51 \\
\hline
\end{tabular}

Table 2: Duration of use of dentures in relation to rendered service

\begin{tabular}{|l|c|}
\hline Duration of use & Numbers (\%) \\
\hline 6 months - 1 year & $38(74.5 \%)$ \\
\hline $2-3$ years & $8(15.6 \%)$ \\
\hline $4-5$ years & $3(5.8 \%)$ \\
\hline 5 years and above & $2(3.9 \%)$ \\
\hline Total & 51 \\
\hline
\end{tabular}

Table 3: Denture-wearing Patients responses to question 7 according to age groups

(Total $\mathrm{n}=51$ )

\begin{tabular}{|c|c|c|c|c|c|c|}
\hline Denture problems & & $\begin{array}{l}50-55 \\
\text { Yrs } \\
(n=8) \%\end{array}$ & $\begin{array}{l}55-60 \\
\text { Yrs } \\
(n=6) \%\end{array}$ & $\begin{array}{l}60-65 \\
\text { Yrs } \\
(n=20) \%\end{array}$ & $\begin{array}{l}65-70 \\
\text { Yrs } \\
(n=14) \\
\%\end{array}$ & $\begin{array}{l}70 \mathrm{Yrs} \\
\text { above } \\
(n=3) \%\end{array}$ \\
\hline Retention problem & Fall during eating & & & & & \\
\hline \multirow[t]{3}{*}{ Upper } & Present & $2(25.0)$ & $2(33.3)$ & 11(55) & $6(42.8)$ & $1(33.3)$ \\
\hline & Some times & $6(75.0)$ & $4(66.6)$ & $6(30.0)$ & $8(57.1)$ & $2(66.6)$ \\
\hline & Absent & $0(0.0)$ & 이 0$)$ & $3(15.0)$ & $0(0.0)$ & $0(0.0)$ \\
\hline \multirow[t]{3}{*}{ Lower } & Present & $5(62.5)$ & $5(83.3)$ & $16(80.0)$ & $11(78.5)$ & $3(100.0)$ \\
\hline & Some times & $3(37.5)$ & $1(16.6)$ & $3(15.0)$ & $5(35.7)$ & $0(0.0)$ \\
\hline & Absent & $0(0.0)$ & $0(0.0)$ & $0(0.0)$ & $0(0.0)$ & $0(0.0)$ \\
\hline \multirow[t]{4}{*}{ Usage problem } & $\begin{array}{l}\text { Feeling pain and } \\
\text { discomfort }\end{array}$ & & & & & \\
\hline & Present & $6(75.0)$ & $4(66.6)$ & $13(65.0)$ & $5(35.7)$ & $2(66.6)$ \\
\hline & Some times & $1(12.5)$ & $2(33.3)$ & $6(30.0)$ & $7(50.0)$ & $1(33.3)$ \\
\hline & Absent & $1(12.5)$ & $0(0.0)$ & $1(5.0)$ & $2(14.2)$ & $0(0.0)$ \\
\hline \multirow[t]{4}{*}{$\begin{array}{l}\text { Mastication } \\
\text { problem }\end{array}$} & $\begin{array}{l}\text { Biting and } \\
\text { chewing difficulty }\end{array}$ & & & & & \\
\hline & Present & $4(50.0)$ & $4(66.6)$ & $14(70.0)$ & $13(92.8)$ & $1(33.3)$ \\
\hline & Sometimes & $3(37.5)$ & $1(16.6)$ & $6(30.0)$ & $1(7.14)$ & $1(33.3)$ \\
\hline & Absent & $1(12.5)$ & $1(16.6)$ & $0(0.0)$ & $0(0.0)$ & $1(33.3)$ \\
\hline
\end{tabular}




\begin{tabular}{|c|c|c|c|c|c|c|}
\hline Aesthetic problem & $\begin{array}{l}\text { Dissatisfaction } \\
\text { about shape \& } \\
\text { color of teeth }\end{array}$ & & & & & \\
\hline & Present & $3(37.5)$ & $0(0.0)$ & $15(75.0)$ & $6(42.8)$ & $2(66.6)$ \\
\hline & Sometimes & $5(62.5)$ & $3(50.0)$ & $5(25.0)$ & $7(50.0)$ & $1(33.3)$ \\
\hline & Absent & $0(0.0)$ & $3(50.0)$ & $0(0.0)$ & $1(7.14)$ & $0(0.0)$ \\
\hline \multirow[t]{4}{*}{$\begin{array}{l}\text { Communication } \\
\text { problem }\end{array}$} & $\begin{array}{l}\text { Difficulty in } \\
\text { speaking }\end{array}$ & & & & & \\
\hline & Present & $4(50.0)$ & $2(33.3)$ & $17(85.0)$ & $9(64.2)$ & $3(100)$ \\
\hline & Sometimes & $2(25.0)$ & $4(66.6)$ & $3(15.0)$ & $2(14.2)$ & $0(0.0)$ \\
\hline & Absent & $2(25.0)$ & $0(0.0)$ & $0(0.0)$ & $3(21.4)$ & $0(0.0)$ \\
\hline
\end{tabular}

were more prominently observed in the elderly aged patients especially over the age of 60 years. Pain was recorded as the most common complaint of these complete denture wearers. No significant relationship could be determined between the patient's gender and type or number of complaints.

\section{DISCUSSION}

All the patients observed in the current study reported problems with their complete dentures. Males outnumbered females, in comparison to other studies with ratio of 1.6: 4.0 female patients. ${ }^{15-16} \mathrm{~A}$ consideration in due with this finding might be that females do not usually seek dental treatments that often. They feel more home-bound in comparison to males. Also public hospitals are not generally their first choice in seeking dental treatment; they might feel more compelled to go to evening based private practices. The results in this study are in agreement with Brunello and Mandikos. ${ }^{17}$ According to their study, most commonly recorded complaints of patients were pain and discomfort (75\%), difficulty in eating (61\%) and ill-fitting dentures $(59 \%)$. Denture bases in these cases were observed as under extended $(86 \%)$ or overextended $(2 \%)$, pressurized oral tissues $(86 \%)$ or had an inadequate posterior palatal seal. $94 \%$ of complete denture wearers showed incorrect jaw relationship while $63 \%$ of patients displayed erroneous tooth positions. Study concluded patient complain of ill-fitting dentures to be associated with problems in retention and difficulty in eating to be related to faults in jaw relationships. Evren et al. (2011) studied elderly people of three different nursing homes $66.6 \%$ of whom were edentulous. In the study of Unluer et al (2007) among 193 of the elderly occupants examined at a nursing home of Ankara Turkey, a mere $7.3 \%$ were observed to possess functional dentition. ${ }^{15}$ The results show an immense need of consideration to the oral health of elderly residents in such establishments. ${ }^{18}$ Aesthetics play a major role in the success of any oral
Oral complaints of complete denture wearing elderly patients

prosthesis. ${ }^{18-20}$ What a clinician perceives as a pleasant appearance may not always be in accord of what the patient had in mind. ${ }^{18,20}$ Patients often have a habit of comparing dentures to their natural teeth with unrealistic expectations. ${ }^{20,21}$ Interestingly, this study reported fewer complaints about the appearance of the dentures from the patients inspite of being the most common complaint otherwise. ${ }^{17,18}$ Psychological, anatomical and constructional put together are the factors on which patient satisfaction with complete dentures depends upon. Davis et $\mathrm{al}^{22}$ examines the difficulty of fabricating dentures for patients with impractical expectations. Patient's pretreatment assumptions influence their end reactions. Finishing and polishing of dentures might contribute to a better fit and function and should be given importance while fabrication. ${ }^{24}$ Along with this incorporation of antifungal agents into acrylic surface might improve the irritant effect of monomer that is associated with denture stomatitis. ${ }^{25}$ This in turn will affect the overall long term use of complete dentures. Regular dental care and oral hygiene maintenance for functional denture fit can influence nutritional risk in elderly people positively. Geriatric dentistry being an individual subject is not given enough importance in Pakistani dental schools. Author of this paper agrees with de Lima et al (2006) about the organization of courses regarding geriatrics and geriatric dentistry. ${ }^{23}$

\section{LIMITATIONS/WEAKNESS}

The main limitation of the current study is the sample size available for consideration. We cannot determine if the findings of the study will remain same when large number of complete denture wearing patients will be evaluated. Also a very concise inclusion criterion had been set for the study participants mainly due to investigators convenience which can be elaborated.

\section{CONCLUSION}

In accord of various previous studies this study also affirms that the elderly patients with complete dentures report a range of complaints regarding chewing of food, communication and social interactions and that these problems escalate with increasing age. Further research is needed to study the relationship of denture complains with the quality of life.

\section{CONFLICT OF INTEREST}

None declared 


\section{REFERENCES}

1. Ikebe k, Walkins CA, Etinger RL,Sajima H, Nokubi T. Application of short from oral health impact profile on elderly Japanese, Gerodontology, 2004;21:167-76.

https://doi.org/10.1111/j.1741-2358.2004.00028.x

2. Leiberg B, Stlize L, Norlen P, wall B. Inadequate dietary habits and mastication in elderly man .Gerodontology 2007;24:41-6. https://doi.org/10.1111/j.1741-2358.2007.00150.x

3. N T, Haori K, Ikebe K, Nokubi, Nag S, Kumakural.Factors influencing eating ability in-patients in a rehabilitation hospitals in Japan. Gerodontology. 2003;20 24-31 https://doi.org/10.1111/j.1741-2358.2003.00024.x

4. Srivastava R, Post insertion complaints in complete denture. Journal of Indian dental association.2011;5(2):304

5. Brunella DL, Mandiks MN .Construction faults, age, gender and relative medical health: factors associated with complaints in complete denture patients. J Prosth. Dent 1998; 79:545-54. https://doi.org/10.1016/S0022-3913(98)70176-3

6. Jeganathan S, Payne JA. Common faults in complete denture: review. Quintessence international( Berlin Germany;1985) 1993;24:483-87

7. Ettinger R. Somme boservatins diagnosis and treatment of complete denture problems. Aust Dent J 1978:23;457-64 https://doi.org/10.1111/j.1834-7819.1978.tb03561.x

8. Rizwan M, Ghani F, Shahzad M. Functional assessment of removable complete dentures. Pak Oral Dent J Vol. 33, n.3 December 2013

9. Smith P , Hughes D . A survey f referred patients experiencing problems with complete dentures. J Prosth Dent 1988; 60:583-86. https://doi.org/10.1016/0022-3913(88)90218-1

10. Kotkin H. Diagnostic significance of denture complaints. J Prosth. Dent 1985; 16:364-67.

11. Celebiæ A, Knezoviæ-Zlatariæ D, Papiæ M, Carek V, Bauciæ I, Stipetiæ J. Factors related to patient satisfaction with complete denture therapy. J Gerontol. Series A. Biological Sciences and Medical Sciences. 2003;58:948-953.

https://doi.org/10.1093/gerona/58.10.M948

12. Allen PF. Assessment of oral health related quality of life. Health and Quality of Life Outcomes.2003;1: 40.

https://doi.org/10.1186/1477-7525-1-40

13. Ikebe k, Nokutubi T, Ettinger RL, Namba H, Tanika N, Iwase $\mathrm{K}$. Dental status and satisfaction with oral function in sample of community -dwelling elderly people in japan. Special care dentistry 2002:22:33-40

https://doi.org/10.1111/j.1754-4505.2002.tb01207.x
14. Evren BA, Ukudmar A, Isre U, ozkan YK. The association between socioeconomic status, oral hygiene practice, denture stomatitis and oral status in elderly people living different residential homes. Gerontology 2011;53:252-257.

https://doi.org/10.1016/j.archger.2010.12.016

15. Kotkin H. Diagnostic significance of denture complaints. J Prosth. Dent 1985; 53:73-77.

https://doi.org/10.1016/0022-3913(85)90070-8

16. Bekinrgli N, Citfi A, Byaraktar K, yayuz A et al. Oral complaints of denture wearing elderly people living in two nursing homes in Istanbul, turkey. Oral health Dent manag. 2012;11:107-15.

17. Brunello DL, Mandikos MN. Construction faults, age, gender, and relative medical health: Factors associated with complaints in complete denture patients. J Prosth. Dent 1998;79:545-54. https://doi.org/10.1016/S0022-3913(98)70176-3

18. Unluer S, Gökalp S, Doðan BG. Oral health status of the elderly in a residential home in Turkey. Gerodontology. 2007;24:22-9 https://doi.org/10.1111/j.1741-2358.2007.00136.x

19. Aizawa F, Kishi M, Moriya T, Takahashi M, Inaba D, Yonemitsu M. The analysis of characteristics of elderly people with high VSC level. Oral Dis.2005;11:80-82

https://doi.org/10.1111/j.1601-0825.2005.01099.x

20. . Nalcaci R, Baran I. Oral malodor and removable complete dentures in the elderly. Oral Surgery, Oral Medicine, Oral Pathol, Oral Radiol Endodo. 2008;105:5-9.1.

https://doi.org/10.1016/j.tripleo.2008.02.016

21. Marshal TA, Warren JJ, Hands JS, XIE X, Stumbo PJ. Oral health, nutrient intake and dietary quality in the very old. J Am Dent Assoc.2002; 133:1369-379.

https://doi.org/10.14219/jada.archive.2002.0052

22. Osterberg T, Carlsson GE. Dental state, prosthodontic treatment and chewing ability: a study of five cohorts of 70- year-old subjects. J Oral Rehabil.2007; 34:553-59.

https://doi.org/10.1111/j.1365-2842.2006.01655.x

23. Lima SMV, Suza EH, Franca CJA. Geriatric dentistry in Brazilian universities. Gerodontology 2006; 23:231-36.

https://doi.org/10.1111/j.1741-2358.2006.00128.x

24. Zafar, Muhammad Sohail and Ahmed, Naseer. 'Nanoindentation and Surface Roughness Profilometry of Poly Methyl Methacrylate Denture Base Materials'. 1 Jan. 2014:573-81.

https://doi.org/10.3233/THC-140832

25. Iqbal Z, Zafar MS. Role of antifungal medicaments added to tissue conditioners: A systematic review. J Prosthodon Res. 2016;60:231-9.

https://doi.org/10.1016/j.jpor.2016.03.006 